\title{
Karać czy rehabilitować? \\ Powojenne ustawodawstwo polskie wobec osób wpisanych na Niemiecką Listę Narodowościową
}

Wśród zadań, przed jakimi stanęły władze państwa polskiego po $1945 \mathrm{r}$., znalazła się skomplikowana kwestia uregulowania statusu osób wpisanych w latach okupacji hitlerowskiej na Niemiecką Listę Narodowościową (NLN) - Deutsche Volksliste (DVL) ${ }^{1}$.

Przeświadczenie o niemieckim rodowodzie zajętych terenów, szczególnie ziem wcielonych do Trzeciej Rzeszy, a także rachuby na ich szybką regermanizację przyczyniły się do objęcia akcją niemczenia większości mieszkańców tych ziem, często polskiej narodowości ${ }^{2}$. W sposób szczególny problem ten dotknął terenów przedwojennego województwa śląskiego i pomorskiego. Wpis do jednej z czterech grup DVL łączył się z uznaniem niemieckiego pochodzenia i nabyciem niemieckiej przynależności państwowej. Dlatego też szybkie uregulowanie prawnego statusu tych osób stało się jednym z bardziej naglących zagadnień z zakresu polityki narodowościowej państwa po $1945 \mathrm{r}$.

${ }^{1}$ Rozporządzenie o Niemieckiej Liście Narodowej i Niemieckiej Przynależności Państwowej na wcielonych ziemiach wschodnich (Verordnung über die Deutsche Volksliste und die Deutsche Staatsangehörigkeit in den eingegliederten Ostgebieten) ukazało się w dniu 4 marca 1941 r. Zob. np. Z. Izdebski, Niemiecka lista narodowa na Górnym Slasku, Katowice-Wrocław 1946; K.M. Pospieszalski, Niemiecka lista narodowa w „Kraju Warty": wybór dokumentów z objaśnieniami w języku polskim i francuskim, Poznań 1949; C. Euczak, „Kraj Warty” 1939-1945. Studium historyczno-gospodarcze okupacji hitlerowskiej, Poznan 1972; idem, Polityka ludnościowa i ekonomiczna hitlerowskich Niemiec w okupowanej Polsce, Poznan 1979, s. 173; C. Madajczyk, Polityka III Rzeszy w okupowanej Polsce, t. I, Warszawa 1970, s. 373; idem, Faszyzm i okupacje. 1938-1945, t. II, Poznań 1984; Documenta Occupationis, t. V, Poznań 1949, s. 119-122.

${ }^{2}$ Tereny te określano jako wcielone ziemie wschodnie (Eingegliedarte Ostgebiete). Zaanektowany obszar obejmował niemal połowę zajętych przez Niemcy ziem polskich oraz czwartą część obszaru państwa polskiego. Zamieszkałe przez ok. 10 mln ludzi terytorium liczyło $91764 \mathrm{~km}^{2}$ powierzchni i obejmowało następujące województwa: pomorskie, poznańskie, górnośląskie, większą część łódzkiego, zachodnią część krakowskiego, Mazowsze, powiat Suwałki, niektóre powiaty województwa kieleckiego wraz z Zagłębiem Dąbrowskim. C. Madajczyk, Faszyzm, s. 66. 
Likwidację skutków zgłoszenia - samodzielnego lub pod przymusem akcesu do Deutsche Volksliste określono mianem rehabilitacji ${ }^{3}$. Budziła ona, zwłaszcza w kontekście przymusu wpisowego oraz obszarów, na których on obowiązywał, silne emocje i skrajne oceny.

Celem niniejszego opracowania jest przedstawienie prawnych rozstrzygnięć regulujących proceder rehabilitacji, który polegał - ogólnie rzecz biorąc na przywróceniu obywatelstwa polskiego. Ustawodawstwo wobec wpisanych na volkslistę ulegało modyfikacjom $\mathrm{z}$ tendencją do łagodzenia kursu represyjnego wobec tych osób tuż po zakończeniu wojny. Początkowo, w dużej mierze pod presją opinii publicznej, ale także wskutek strategii legitymizacji ośrodka rządowego, polegającej na podsycaniu antyniemieckich odczuć społecznych - wpis na DVL, stając się częścią tzw. kwestii niemieckiej, budził powszechną pogardę. W świadomości społecznej każda osoba naznaczona tzw. grupa jawiła się jako volksdeutsch, którego posądzano o zdradę narodu i państwa ${ }^{4}$. Nie starano się przy tym dociekać powodów wpisu na volkslistę ani też różnicować położenia czy postawy wojennej jej reprezentanta. Wrogi stosunek ogółu społeczeństwa do tej kategorii często udaremniał jej ponowną integrację $\mathrm{i}$ identyfikację z państwem polskim ${ }^{5}$.

Taka sytuacja znalazła odzwierciedlenie w objęciu osób podlegających rehabilitacji surowemu osądowi, a w konsekwencji - regulacjom prawnym skierowanym wobec tzw. zdrajców narodu polskiego.

Cele polityczne związane $\mathrm{z}$ poszukiwaniem poparcia dla Polskiej Partii Robotniczej (PPR) w możliwie szerokich kręgach społecznych, w tym także w środowisku osób posiadających wpis na DVL, skutkowały przyjęciem koncepcji tzw. szerokiej rehabilitacji. W konsekwencji kolejne zmiany w ustawodawstwie rehabilitacyjnym systematycznie umożliwiały przyznanie obywatelstwa polskiego coraz większej liczbie osób.

Jeszcze w okresie wojny działające w kraju i na emigracji ugrupowania polityczne rozważały i opracowywały koncepcje postępowania wobec osób, które dopuściły się zdrady narodu polskiego. Polskie Państwo Podziemne dysponowało wiedzą o akcji niemczenia na poszczególnych terenach okupowanych. Zdawano sobie sprawę, że akt przyjęcia volkslisty stanowił skomplikowany problem, który oprócz wymiaru prawnego, posiadał także aspekt polityczny,

${ }^{3}$ Odrębne zagadnienie stanowi proces weryfikacji narodowościowej, niekiedy mylnie utożsamiany $\mathrm{z}$ procederem rehabilitacji. Proces weryfikacji związany był z przejęciem przez Polskę w 1945 r. wschodnich obszarów Niemiec na mocy układów poczdamsko-jałtańskich. Zamieszkująca je ludność posiadała obywatelstwo niemieckie, co wiązało się z koniecznością przeprowadzenia wyraźnego podziału między Polakami a Niemcami, nadaniu tym pierwszym obywatelstwa polskiego i wysiedleniu z granic państwa polskiego tych drugich. Weryfikację reklamowano jako akt prawnoporządkowy służący ustaleniu przynależności narodowej w drodze procedury administracyjnej, której istotę i przebieg określały i regulowały odrębne przepisy prawne.

${ }^{\dagger}$ Por.: J. Sawicki, O prawie squdów specjalnych, w: Wymiar sprawiedliwości w odrodzonej Polsce, 22 VII 1944-22 VII 1945, Warszawa 1945, s. 55.

5 P. Madajczyk, Niemcy polscy 1944-1989, Warszawa 2001, s. 36. 
społeczny i moralny. Wiedziano, że rozwiązanie zagadnienia DVL będzie zadaniem trudnym i odpowiedzialnym, zwłaszcza na ziemiach włączonych do Trzeciej Rzeszy. Dlatego też w strukturach Delegatury Rządu RP na Kraj powstawały propozycje likwidacji skutków wpisu na DVL na tym obszarze ${ }^{6}$.

Zakończenie działań wojennych i bezwarunkowa kapitulacja Trzeciej Rzeszy otworzyły okres rozliczania niemieckich zbrodni przeciwko ludzkości oraz zbrodni wojennych. W krajach okupowanych tworzono specjalne, odrębne ustawodawstwo karne wymierzone przeciwko osobom współpracującym z okupantem ${ }^{7}$. Warto zaznaczyć, że sytuacja powstała wówczas w Polsce, tj. uzależnienie od ZSRR, wykluczała możliwość osądzenia sowieckich zbrodni dokonanych w czasie wojny. Kształtujący się komunistyczny ośrodek polityczny nie chciał i nie mógł wysuwać oskarżeń w stosunku do obecnego gwaranta zdobycia władzy w kraju. Stąd polskie tymczasowe ustawodawstwo i judykatura odzwierciedlały przestępstwa związane z działalnością tylko jednego okupanta - Trzeciej Rzeszy.

Nowa doktryna prawa karnego sprowadzała się do uzasadniania uchwalania licznych rozporządzeń karnych faktem „wyzwalania” obszarów polskich spod terroru okupacji hitlerowskiej ${ }^{8}$. Powojenna władza przyjęła koncepcję ustanowienia odrębnych rozporządzeń prawa karnego, zawierających ujęcie zbrodni wojennych i kolaboracji z niemieckim okupantem ${ }^{9}$. Intencja ustawodawcy w tym zakresie było objęcie jurysdykcją jak największej liczby osób. Pierwsze dekrety i rozporządzenia nie zawierały precyzyjnego opisu konkretnych zachowań zagrożonych kara. Podkreśla się, że ówczesne ,,dyspozycje przestępstw były niekompletne (niedookreślone), a zawarte w nich znamiona ocenne i nieostre. W związku z tym orzecznictwo sądów w nieporównanie większym stopniu niż w innych rodzajach spraw spełniało tutaj istotna, twórczą funkcję"10 .

Pierwszym aktem prawnym, mającym likwidować skutki wojny i okupacji, był dekret PKWN z 31 sierpnia 1944 r. O wymiarze kary dla faszystowsko-hitlerowskich zbrodniarzy winnych zabójstw i znęcania się nad ludnościa cywilnq i jeńcami wojennymi oraz dla zdrajców Narodu Polskiego ${ }^{11}$. W litera-

${ }^{6}$ Zob. np. Archiwum Muzeum Stutthof [dalej: AMS], Kol. Archiwum Urzędu Ochrony Państwa w Bydgoszczy [dalej: Kol. AUOP-B[, K-1-16, Problem niemiecki na Ślasku (Przyczynki do likwidacji niemczyzny w Polsce), s. 18-34. Por. Z. Boda-Krężel, Koncepcje rozwiazania problemu niemieckiej listy narodowościowej przez polskie środowiska polityczne i wladze konspiracyjne w okresie okupacji, „Śląski Kwartalnik Historyczny Sobótka” 1969, nr 3, s. 341-344.

A. Pasek, Przestepstwa okupacyjne w polskim prawie karnym z lat 1944-1956, Wrocław 2002 , s. 13

${ }^{8}$ W. Wolter, Prawo karne. Zarys wykladu systematycznego. Część ogólna. Ustawa karna i przesteppstwo na tle kodeksu karnego z 1932 r., kodeksu karnego Wojska Polskiego z 1944 r. oraz dekretów od 1944 do 1946 r., Warszawa 1947, s. 18.

${ }^{9}$ Szerzej na temat powojennego ustawodawstwa z dziedziny prawa karnego zob. Z.A. Ziemba, Prawo przeciwko spoleczeństwu. Polskie prawo karne w latach 1944-1956, Warszawa 1997.

A. Pasek, Przestepstwa okupacyjne, s. 35.

Dz.U. RP, nr 4, 1944 r., poz. 16. Dekret ten wszedł w życie z dniem 13 września 1944 r. Został znowelizowany dekretem z 10 grudnia 1946 r.: Dz.U. RP, nr 69, 1946 r., poz. 377. 
turze bywa on określany także „dekretem sierpniowym”12 lub „sierpniówką,"13. To właśnie ten akt karnoprawny uchwalony przez nową władzę miał rozliczyć zbrodnie wojenne oraz różne formy współpracy z okupantem podczas drugiej wojny światowej. Przy czym dekret sierpniowy stanowił podstawę represji karnej zarówno w stosunku do obywateli obcych państw, jak też obywateli państwa polskiego współpracujących $\mathrm{z}$ okupantem niemieckim, którzy dopuścili się „zdrady czynnej”14. Dyspozycja ta zawierała między innymi takie przestępstwa, jak: zabójstwa, znęcanie się, prześladowanie ludności cywilnej lub jeńców wojennych, działanie na szkodę osób przebywających na obszarze państwa polskiego, a w szczególności poszukiwanych bądź prześladowanych przez władze okupacyjne. Za te czyny dekret przewidywał karę śmierci, karę więzienia do 15 lat lub dożywotnio, utratę praw publicznych i obywatelskich praw honorowych lub konfiskatę mienia skazanego lub też rodziny. Do rozpatrywania przestępstw objętych „sierpniówką" wyznaczone zostały specjalne sądy karne [dalej: SSK], które powołał do życia dekret PKWN z 12 września 1944 r. ${ }^{15}$ Działały one do 17 października 1946 r. na obszarach okręgów sq̨ó́w apelacyjnych, kiedy ich kompetencje przejęły sądy okręgowe ${ }^{16}$. Omawiany dekret stosowany był wobec czynów popełnionych po 31 sierpnia, co, z uwagi na łamanie zasady lex retro non agit, rodziło pewne polemiki wśród prawników $^{17}$. Pojawiały się opinie, że stosowanie tej reguły prawnej nie jest możliwe jako sprzeczne $\mathrm{z}$ podstawowymi zasadami moralności ${ }^{18}$. Wskazywano także na społeczną potrzebę zastosowania prawa wyjątkowego wobec zbrodniarzy i kolaborantów hitlerowskich, w tym wymierzanie im szczególnie surowych $\operatorname{kar}^{19}$. Warto nadmienić, że na gruncie filozofii prawa i filozofii polityki podkreśla się negatywny wpływ, jaki niesie ze sobą uzdrawianie niedomagań ży-

${ }^{12}$ K. Stryjkowski, Polożenie osób wpisanych w Wielkopolsce na niemiecka listę narodowościowa w latach 1945-1950, Poznań 2004, s. 403.

$1^{1:}$ A. Pasek, Przestepstwa okupacyjne, s. 20.

${ }^{14} \mathrm{M}$. Muszkat, Wymiar sprawiedliwości w stosunku do przestępców wojennych a walka o utrwalenie pokoju, „Demokratyczny Przegląd Prawniczy” 1946, nr 11/12, s. 15.

${ }^{15}$ Dz.U. RP, nr 4, 1944 r., poz. 21. Szerzej na temat tego dekretu zob. B. Kopka, Obozy pracy w Polsce 1944-1950. Przewodnik encyklopedyczny, Warszawa 2002, s. 32-33; zob. też Sad Specjalny Karny w Gdańsku, „Dziennik Bałtycki” 1946, nr 84, s. 4.

${ }^{16}$ Dz.U. RP, nr 59, 1946 r., poz. 324. Zob. też Archiwum Państwowe w Gdańsku [dalej: AP Gd], Urząd Wojewódzki [dalej: UW], 1164/365, Wojewódzka Komisja Weryfikacyjna [dalej: WKW], k. 166; Archiwum Akt Nowych [dalej: AAN], Ministerstwo Administracji Publicznej [dalej: MAP], 199/766, Rehabilitacja osób wpisanych na niemieckie listy narodowościowe - stanowisko wladz państwowych i spoleczeństwa. Rozporządzenia, sprawozdania, ankiety, deklaracje lojalności, korespondencja, k. 129.

Zob. np. J. Sawicki, T. Cyprian, Prawo polskie w walce z hitleryzmem i kolaboracjonizmem, „Demokratyczny Przegląd Prawniczy” 1946, nr 11/12, s. 14-15; L. Kubicki, Zbrodnie wojenne w świetle prawa polskiego, Warszawa 1963, s. 69-72; A. Pasek, Przestepstwa okupacyjne, s. 46-49.

${ }_{18}$ A. Landau, C. Wasilkowski, Odpowiedzialność za zbrodnie czasu wojny w prawie polskim, „Demokratyczny Przegląd Prawniczy” 1946, nr 11/12, s. 35

19 J. Sawicki, B. Walawski, Zbiór przepisów specjalnych przeciwko zbrodniarzom hitlerowskim i zdrajcom narodu z komentarzem, Kraków 1945, s. 18; L. Kubicki, Zbrodnie wojenne, s. 71. 
cia publicznego poprzez uchwalanie licznych ustaw, a także działanie prawa wstecz. Rodzi to - podkreślano - złudne uspokojenie oraz błędne przekonanie rozwiązania problemu. Prowadzi też do destabilizacji życia prawnego, w tym niepożądanych luk w prawie oraz nieznajomości przepisów prawnych nie tylko wśród obywateli, ale też wśród urzędników. Nadmierna działalność prawotwórcza skutkuje poczuciem niepewności, obniżeniem rangi prawa, jest także wyrazem braku zaufania wobec społeczeństwa ${ }^{20}$.

Zagadnienie osób, które w latach 1939-1945 odstapiły od narodowości polskiej nie zostało ujęte wprost w omawianym dekrecie. Natomiast uzyskało ono w doktrynie powojennego ustawodawstwa karnego miano ,zdrady biernej", dla której powstały osobne rozporządzenia ${ }^{21}$. Jednakże wskazany wyżej zamysł konstrukcji prawnej, zmierzający do objęcia swym zasięgiem jak największej liczby przestępstw wojennych i okupacyjnych, skutkował tym, że z dekretu sierpniowego często osądzane były oba rodzaje wyżej wymienionych przestępstw. Jednocześnie problem odstępstwa od narodowości polskiej był stale obecny w trakcie gromadzenia materiału dowodowego przeciwko obywatelom polskim w sprawach rozpatrywanych na podstawie „sierpniówki". Wiązało się to z wykorzystywaniem zarówno tego dekretu, jak i późniejszych aktów prawnych dotyczących rozwiązania problemu NLN, do represjonowania osób postrzeganych przez władze jako niebezpieczne ${ }^{22}$. Na gruncie teorii prawa karnego wyjaśniano, że dekret sierpniowy stwarzał „,bardziej syntetyczną konstrukcję prawna, zbliżająca przepis prawny do konkretnego fenomenu społecznego"23. I właśnie to zbiorowe ujęcie ustawodawcze uczyniło $\mathrm{z}$ omawianego dekretu skuteczne narzędzie surowej represji nie tylko za zbrodnie wojenne, ale głównie za współpracę z okupantem ${ }^{24}$. Często dopiero powojenne orzecznictwo sądowe ustalało, jakie zachowanie z okresu okupacji nosiło znamiona „zdrady czynnej”. Teoretycznie moc dekretu sierpniowego rozciagała się na tereny tzw. Polski lubelskiej. Wiadomo jednak, że na jego podstawie władze sowieckie wywoziły, między innymi z terenów województwa gdańskiego, w głąb ZSRR, obok ludności niemieckiej, także osoby posiadające dowód wpisu na DVL.

Przestępstwa zawarte $\mathrm{w}$ dekrecie sierpniowym miały charakter wykroczeń powszechnych, czyli takich, które mogą być popełnione przez każdego ${ }^{25}$. Natomiast zdarza się, że ustawodawca zawęża krąg podmiotów zdolnych do popełnienia danego przestępstwa do osób o pewnych konkretnych cechach określonych przez ustawę. Wówczas mamy do czynienia z wykroczeniami

${ }^{20}$ M. Szyszkowska, Zwiazki filozofii polityki z filozofia prawa, w: Elementy filozofii polityki, red. M. Szyszkowska, Warszawa 1992, s. 60-61

${ }^{21}$ Zob. J. Sawicki, O prawie, s. 58; J. Sawicki, T. Cyprian, Prawo polskie, s. 15.

22 A. Piasek, Przestepstwa okupacyjne, s. 36-38.

${ }^{23}$ L. Kubicki, Zbrodnie wojenne, s. 71.

24 A. Piasek, Przestepstwa okupacyjne, s. 49.

25 Por. K. Buchała, A. Zoll, Polskie prawo karne, Warszawa 1997, s. 139. 
o charakterze indywidualnym ${ }^{26}$. Do nich wypada zaliczyć odstępstwo od narodowości, gdyż zakres podmiotowy zdolny do jego popełnienia ograniczony został do kręgu obywateli polskich ${ }^{27}$.

Odstępstwo od narodowości polskiej oraz orzecznictwo wobec osób, które się jego dopuściły, stało się przedmiotem dekretu PKWN z 4 listopada $1944 \mathrm{r}$. $O$ środkach zabezpieczajacych $w$ stosunku do zdrajców Narodu ${ }^{26}$. Dekret ten nie był ustawa karna, jakkolwiek zawierał środki o charakterze represyjnym ${ }^{29}$. Obowiazywał on na obszarze byłego Generalnego Gubernatorstwa oraz województwa białostockiego. Natomiast jego przepisy mogły zostać również rozciagnięte na pozostałe obszary Polski, po uprzednim wydaniu odnośnych rozporządzeń przez ministrów: sprawiedliwości, bezpieczeństwa publicznego oraz gospodarki narodowej i finansów. Jednak kierownicy tych resortów nigdy nie skorzystali z przyznanych im uprawnien. W rozporządzeniu tym do grona „zdrajców narodu" zaliczono: obywateli polskich, którzy w okresie okupacji niemieckiej bądź zadeklarowali przynależność do narodowości niemieckiej lub pochodzenie niemieckie, bądź korzystali z praw i przywilejów z tytułu przynależności do narodowości niemieckiej lub pochodzenia niemieckiego. Wszystkie osoby, które ukończyły 13 lat i wobec których istniało podejrzenie popełnienia czynów określonych w omawianym dekrecie podlegały umieszczeniu na czas nieoznaczony w miejscu odosobnienia (obozie) oraz poddaniu przymusowej pracy. Zatrzymanie i skierowanie do obozu pracy następowało na wniosek prokuratora Specjalnego Sądu Karnego ${ }^{30}$. Do jego natychmiastowego wykonania zobowiązano organa bezpieczeństwa publicznego ${ }^{31}$. „Zdrajcy narodu" tracili prawa publiczne, obywatelskie prawa honorowe, natomiast ich majątek (oraz rodzin) podlegał zajęciu przez Skarb Państwa ${ }^{32}$. W przypad-

26 Ibidem, s. 140.

27 Doktryna prawa karnego wyróżnia dodatkowo przestępstwa indywidualne właściwe: gdy czynu dopuszcza się osoba, niemająca wymaganej przez ustawę właściwości, wówczas nie stanowi on w ogóle przestępstwa, oraz wykroczenia niewłaściwe: gdy szczególna właściwość podmiotu wpływa tylko na ciężar popełnionego wykroczenia, podwyższając lub obniżając wymiar kary, jednak nie stanowi warunku przestępczości czynu. Ponieważ odstępstwo od narodowości polskiej nie mogło być popełnione przez osobę nie mającą obywatelstwa polskiego, a więc nie stanowiło w ogóle przestępstwa, należy zaliczyć go do wykroczeń opisanych jako indywidualne właściwe. Zob. A. Pasek, Przestepstwa okupacyjne, s. 44.

${ }^{28}$ Dz.U. RP, nr 11, 1944 r., poz. 54. Dekret wszedł w życie 13 listopada 1944 r.; L. Olejnik, Polityka narodowościowa Polski w latach 1944-1960, Łódź 2003, s. 147.

29 A. Pasek, Przestepstwa okupacyjne, s. 34.

${ }^{30}$ Prokurator zobowiązany był do powierzenia tymczasowej opieki nad nieletnimi (jeśli istniała taka konieczność) gminnym lub miejskim radom narodowym. Ponadto do jego obowiązków należało zwrócenie się do właściwego urzędu skarbowego o dokonanie protokolarnego zajęcia majątku. Następnie majątek zatrzymanego (ruchomy i nieruchomy) należało powierzyć miejscowej radzie narodowej pod tymczasowy nadzór.

${ }^{31}$ Przepisy wykonawcze do dekretu listopadowego wydały ministerstwa: Sprawiedliwości, Bezpieczeństwa Publicznego oraz Gospodarki Narodowej i Finansów w dniu 30 listopada 1944 r., natomiast weszły one w życie 13 grudnia tego roku. Dz.U. RP, nr 14, 1944 r., poz. 75.

32 Tymczasowego zatrzymania podejrzanych wraz $\mathrm{z}$ rodzinami oraz zabezpieczenia majątku dokonywały władze bezpieczeństwa. 
ku braku dowodów na dopuszczenie się przestępstw określonych dekretem listopadowym sąd mógł uchylić decyzję prokuratora. Wówczas następował zwrot skonfiskowanego majątku lub też jego równowartości. Dekret przewidywał także karę śmierci lub dożywotniego więzienia za pomoc udzielaną osobom zatrzymanym i oskarżonym o odstępstwo od narodowości polskiej33. Od odpowiedzialności karnej zwolniono działaczy podziemnych organizacji niepodległościowych, którzy przyjęli niemiecką narodowość w celu prowadzenia działań konspiracyjnych ${ }^{34}$.

Jesienią 1944 r., po konsultacjach przedstawicieli PKWN i KRN w Moskwie, podjęto decyzję o przyśpieszeniu radykalnych działań w celu zlikwidowania wszelkiego oporu wobec władzy i ubezwłasnowolnienia społeczeństwa. Wszczęto kroki w kierunku izolacji społecznej oraz dyskryminacji osób wpisanych na volkslistę. W dniu 21 października 1944 r. Stanisław Radkiewicz, szef Ministerstwa Bezpieczeństwa Publicznego (MBP), wydał rozporządzenie o organizowaniu obozów dla posiadaczy volkslisty ${ }^{35}$. Natomiast 30 października tego roku dekretował Instrukcję o przetrzymaniu i odestaniu do obozów pracy zdrajców Narodu tzw. Volksdeutschów. Otrzymały ją wojewódzkie, powiatowe i miejskie urzędy bezpieczeństwa publicznego (UBP) oraz komendy Milicji Obywatelskiej (MO) ${ }^{36}$. Wszyscy volksdeutsche, majacy ukończone 16 lat mieli być zatrzymani i odesłani do obozów pracy. Członkowie rodzin zatrzymanych otrzymywali adnotację w dokumentach osobistych: „rodzina volksdeutscha" ${ }^{37}$. Jednocześnie wśród pierwszych projektów uchwał Biura Politycznego (BP) Komitetu Centralnego (KC) PPR znalazł się projekt zorganizowania obozów izolacyjnych dla osób wpisanych na DVL oraz ich aresztowanie do 11 listopada $1944 \mathrm{r}^{38}$

I tak w atmosferze wrogości wobec wszystkiego co niemieckie oraz towarzyszącej jej chęci odwetu za doznane krzywdy, a przede wszystkim w trakcie toczącej się jeszcze wojny, powstawały (omówione wyżej) pierwsze akty prawne, mające uregulować problem odstępstwa od narodowości polskiej. Jeszcze w czasie trwania akcji rehabilitacji oceniano, że ówczesny klimat polityczny nie sprzyjał subtelnej pracy ustawodawczej ${ }^{39}$. Dostrzegano również problem zbytniego pośpiechu przy tworzeniu aktów prawodawczych oraz

${ }^{33}$ Dz.U. RP, nr 11, 1944 r., poz. 54.

${ }^{34}$ M. Piekarski, Wylqczenie wrogich elementów ze spoleczeństwa polskiego i rehabilitacja. Zarys wyjaśniajacy, Gdynia 1946, s. 91.

35 A. Kochański, Polska 1944-1991. Informator historyczny, t. I, Warszawa 1996, s. 39; L. Olejnik, Zdrajcy narodu? Losy volksdeutschów w Polsce po II wojnie światowej, Warszawa 2006, s. 74.

${ }^{36}$ L. Olejnik, Zdrajcy, s. 74.

${ }^{37}$ L. Olejnik, Polityka narodowościowa, s. 146-147; E. Mironowicz, Polityka narodowościowa PRL, Białystok 2000, s. 35.

${ }^{38}$ Protokoty z posiedzeń Biura Politycznego KC PPR 1944-1945, oprac. A. Kochański, Warszawa 1992, s. 48.

${ }^{39}$ M. Muszkat, Wymiar sprawiedliwości, s. 15. 
braku dostatecznego rozeznania zagadnienia ${ }^{40}$. Jednocześnie pojawiały się opinie, że Polska odegrała pionierską rolę w dziedzinie antyhitlerowskiego ustawodawstwa ${ }^{41}$.

Omówione wyżej dekrety PKWN oraz pierwsze posunięcia władz pokazały, że wstępne założenie, jakim kierowała się powojenna władza wobec posiadaczy volkslisty, sprowadzało się do ich odizolowania od reszty społeczeństwa. Brak określenia terminu w kwestii dyspozycji „odosobnienia” wskazywałby na nieistnienie wówczas spójnej koncepcji odnośnie do ustawodawczego rozwiązania dotyczącego odstępstwa od narodowości polskiej w czasie niemieckiej okupacji. Jak pokazało brzmienie dekretu listopadowego, kierowano się wówczas zasadą stosowania „środków zabezpieczających"42. Wydaje się, że ustawodawca w dużej mierze działał pod wpływem odczuć opinii społecznej wobec osób o chwiejnej postawie narodowej w trakcie dopiero co zakończonej wojny ${ }^{43}$. Ponadto, jak już wspomniano, politycy komunistyczni nadający kierunek ówczesnym rozwiązaniom, w tym i prawnym, zbyt mocno zajęci byli działaniami, mającymi na celu przejęcie władzy w kraju. Stąd sprawę, jak to wówczas określano, volksdeutschów, odkładano na potem.

Istniały jednak środowiska, zwłaszcza skupione wokół reaktywowanego w listopadzie 1944 r. Polskiego Związku Zachodniego (PZZ), podkreślające wagę rozwiązania omawianej kwestii ${ }^{44}$. Wskazywano, że dekret listopadowy nie może mieć zastosowania, przede wszystkim na ziemiach polskich wcielonych w czasie wojny do Trzeciej Rzeszy ${ }^{45}$.

Niedoskonałości dotychczasowego ustawodawstwa w zakresie ujednolicenia statusu prawnego i sposobu postępowania wobec osób wciagniętych na Niemiecką Listę Narodową, zwłaszcza w odniesieniu do mieszkańców Pomorza i Śląska, starano się uregulować dekretem $O$ wyłaczeniu ze społeczeństwa polskiego wrogich elementów z 28 lutego $1945 \mathrm{r}^{46}$ Dokument ten gwarantował automatyczne przywrócenie obywatelstwa polskiego obywatelom państwa polskiego na obszarach Rzeczypospolitej Polskiej, wcielonych do Trzeciej Rzeszy, oraz na obszarze byłego Wolnego Miasta Gdańska wpisanym na Deutsche Volksliste po dniu 31 sierpnia 1939 r. Rozgraniczono tu reprezentantów DVL na osoby wpisane do III i IV grupy oraz te, które zaliczo-

40 A. Landau, C. Wasilkowski, Zagadnienie tzw. volksdeutschów w świetle prawa, „Demokratyczny Przegląd Prawniczy" 1946, nr 9/10, s. 6.

41 L. Chajn, Kiedy Lublin byt Warszawq, Warszawa 1964, s. 41-42.

${ }^{42}$ A. Landau, C. Wasilkowski, Zagadnienie tzw. volksdeutschów, s. 6.

43 J. Sawicki, T. Cyprian, Prawo polskie, s. 16.

44 PZZ stanowił po wojnie największą zorganizowaną siłę społeczną, działającą na rzecz repolonizacji ziem odzyskanych ze szczególnym uwzględnieniem problemów narodowościowych. M. Ujdak, Polski Zwiazek Zachodni wobec problemów narodowościowych w latach 1944-1950, Katowice 1988 , s.8.

${ }^{45}$ M. Musielak, s. 238-239.

${ }^{46}$ Dz.U. RP, nr 7, 1945 r. poz. 30; J. Rados, Rehabilitacja na Pomorzu Gdańskim, Gdańsk 1969, s. 57. 
no do II grupy ${ }^{47}$. Natomiast pominięte zostały osoby przynależne do I grupy (Reichsdeutsche) jako przedstawiciele wyłącznie narodu niemieckiego. Rehabilitacja eingedeutschów odbywać się miała przed urzędnikiem administracji I instancji, volksdeutschow zaś w sądach grodzkich ${ }^{48}$. W przypadku odmowy rehabilitacji następowały umieszczenia na czas nieokreślony w miejscu odosobnienia, poddanie przymusowej pracy, utrata majątku, praw publicznych oraz obywatelskich praw honorowych. Warunkiem pozytywnej rehabilitacji było udowodnienie przymusowego wciagnięcia na DVL oraz braku działania w czasie okupacji na szkodę narodu i państwa polskiego. Ponadto osoby zainteresowane odzyskaniem pełni praw obywatelskich zobowiązane zostały do złożenia pisemnej Deklaracji wierności Narodowi i demokratycznemu Państwu Polskiemu. W okresie 10 lat od przyznania rehabilitacji prokurator Specjalnego Sądu Karnego mógł żądać ponownego rozpoznania sprawy w przypadku ujawnienia nieznanych dotąd okoliczności.

Powyższy dekret nie nabrał mocy prawnej z uwagi na zbyt łagodną procedurę, zakładającą automatyczne włączenie zniemczonych do narodu i państwa polskiego, jako niepozwalającą na szybkie odizolowanie „wrogów polskiej sprawy"49. Wątpliwości te formułowano głównie w stosunku do obszarów przedwojennego pogranicza polsko-niemieckiego ${ }^{50}$. Z pewnością obiekcje te wiązały się z nieznajomością warunków, w jakich znalazła się ludność interesującego nas obszaru w czasie okupacji. Brak wiedzy w tym zakresie budził nieufność warstwy urzędniczej, a także opinii publicznej wobec osób, które znalazły się na DVL. Swoją opinię na temat dekretu ponownie wyraził także Polski Związek Zachodni. Za niedopracowane elementy uznał między innymi brak określenia terenów, na których występował przymus wpisania na volkslistę ${ }^{51}$, prowadzenie procesów rehabilitacyjnych przez sądy bez odwoływania się do organizacji społecznych oraz zły system kar przewidzianych za wyłączenie ze społeczeństwa polskiego ${ }^{52}$. Dażąc do szybkiego przeprowadzenia rehabilitacji jak największej liczby osób oraz w celu oczyszczenia atmosfery

${ }^{47}$ R. Wapiński, Pierwsze lata władzy ludowej na Wybrzeżu Gdańskim, Gdańsk 1970, s. 68.

${ }^{48}$ Warto odnotować, że wśród ścisłego gremium kierowniczego PPR pojawiały się postulaty indywidualnego rozpatrywania spraw osób posiadających ,grupe" w na drodze sądowej, zob. E. Gierek, Smak życia. Pamiętniki, Warszawa 1993, s. 60.

${ }_{49}$ Dekret ten utracił moc prawną na podstawie obwieszczenia Ministra Sprawiedliwości z 7 maja 1945 r. Dz.U. RP, nr 17, 1945 r., poz. 96. Wyjaśniano, iż niezatwierdzenie dekretu nastapiło z uwagi na nieprzedłożenie go do zatwierdzenia Krajowej Radzie Narodowej. M. Musielak, s. 239240. Innym poglądem wyrażanym w literaturze na temat powodu niezatwierdzenia tego dekretu jest ujawnianie nowych dokumentów dotyczących warunków wpisu i sytuacji prawnej wpisanych na NLN, co wymagało uwzględnienia w prawie rehabilitacyjnym. Zob. J. Rados, Rehabilitacja na Pomorzu Gdańskim, Gdańsk 1969, s. 58-59.

${ }^{50}$ C. Osękowski, Spoleczeństwo Polski zachodniej i pótnocnej w latach 1945-1956. Procesy integracji i dezintegracji, Zielona Góra 1994, s. 100.

${ }^{51}$ Postulat ten zgłaszany był głównie na obszarze Wielkopolski, gdzie, jak już pisano, nie istniał przymus wpisowy, zob.: K. Stryjkowski, Polożenie osób, s. 407.

${ }^{52}$ C. Osękowski, Spoleczeństwo, s. 101. 
wokół zagadnienia volkslisty, PZZ postulował zobowiązanie władz administracyjnych do publikowania listy osób, które złożyły Deklarację wierności, będącą podstawą do wystawiania zaświadczeń rehabilitacyjnych. Związek postulował również dopuszczenie go do współdziałania w kwestii opiniowania spraw rehabilitacyjnych. Ponadto w opinii PZZ przepisy dekretu lutowego nie dawały możliwości osądzenia osób, które odstapiły od narodowości polskiej na terenach na wschód od Bugu, a następnie znalazły się na terenie Polski centralnej i zachodniej. Postulowano także rozszerzenie dekretu listopadowego tak, by mógł on objać swoim zasięgiem całą ludność wpisaną na DVL ${ }^{53}$. Z inicjatywy Ministerstwa Sprawiedliwości w styczniu 1945 r. powstały opinie w tym zakresie. Sugerowano w nich między innymi internowanie lub zamknięcie w obozie na wniosek prokuratora Specjalnego Sądu Karnego osób, także tych, które zostały wpisane na DVL pod przymusem, w innym zaś dokumencie wskazywano, że osoby te pomimo wpisu wykazywały polską postawę narodową w czasie okupacji, w związku $\mathrm{z}$ czym postulowano złagodzenie niektórych przepisów ${ }^{54}$.

Wśród innych inicjatyw prawnych dotyczących unormowania sytuacji osób wpisanych na DVL znalazł się także projekt Biura Ziem Zachodnich (BZZ), utworzonego w lutym 1945 r. przy Radzie Ministrów ${ }^{55}$. Zawarte w nim propozycje odnosiły się do ziem wcielonych do Rzeszy oraz byłego Wolnego Miasta Gdańska. Projekt postulował prawo do rehabilitacji wszystkim czterem grupom volkslisty, wskazując na warunek przymusu oraz zachowanie polskiej odrębności narodowej w czasie okupacji, który musiał zaistnieć, by odzyskać pełnię praw obywatelskich. Planowano także przyznać prawo do rehabilitacji członkom organizacji niepodległościowych. Zawarte tu koncepcje znalazły odzwierciedlenie w przyjmowanych ustawach dotyczących odstępstwa od narodowości polskiej.

W kwietniu 1945 r. minister administracji publicznej, Edward Ochab, przesłał do Komisji Prawniczej przy Ministerstwie Sprawiedliwości pismo, w którym podkreślał, że na terenie województw łódzkiego i poznańskiego nie może być stosowany liberalny tryb przywracania praw obywatelskich osobom wpisanym do III i IV grupy DVL, ponieważ mogłoby to wywołać silne i uzasadnione oburzenie społeczne. Wiedza, która docierała do ministra wraz ze sprawozdaniami wojewodów, opierała się na fakcie, że przymus okupanta przy wcielaniu na listę narodową na tych terenach był minimalny ${ }^{56}$. Korespondencja dotycząca projektów rozporządzeń w sprawie rehabilitacji, wymienia-

53 AAN, MAP,199/766, Rehabilitacja osób wpisanych na niemieckie listy narodowościowe, k. 32 i 58. Por. K. Stryjkowski, Potożenie osób, s. 408.

54 L. Olejnik, Zdrajcy, s. 88-89.

55 AAN, MAP, 199/2387, Projekty dekretów i zarzqdzeń dotyczacych Ziem Odzyskanych, k. 32-35.

56 AAN, MAP, 199/766, Rehabilitacja osób wpisanych na niemieckie listy narodowościowe, k. 33 i 42 . 
na na szczeblu ministerialnym, uwidacznia zależność tworzenia rozwiązań prawnych od sukcesywnie zdobywanej wiedzy na temat nazistowskiej polityki bezpośredniej germanizacji na terenie Pomorza.

Kolejny akt prawny, przyjęty tym razem bez zastrzeżeń, likwidujący skutki niemieckiej polityki narodowościowej okresu wojny wobec osób wpisanych na NLN ukazał się 6 maja $1945 \mathrm{r}^{57}$, a towarzyszące mu przepisy wykonawcze wydano 25 i 26 maja tego $\mathrm{roku}^{58}$. Wydanie ustawy $O$ wylaczeniu ze spoleczeństwa polskiego wrogich elementów poprzedziły przygotowane przez Ministerstwo Administracji Publicznej projekty rozporządzeń: $O$ wytaczeniu wrogich elementów oraz $W$ sprawie rehabilitacji osób wpisanych do trzeciej $i$ czwartej grupy niemieckiej listy narodowej lub do grupy tzw. Leistungs-Pole ${ }^{59}$. Ustawa, pomimo iż utrzymała zasadę stosowania „,środków zabezpieczających” ustanowionych w dekrecie listopadowym, uznawana jest jako „krok w kierunku przyjęcia rozwiązań właściwych dla powszechnego prawa karnego"60.

Rozporządzenie objęło obywateli polskich wpisanych po 31 sierpnia 1939 r. na terenach wcielonych do Trzeciej Rzeszy (oprócz województwa białostockiego) do II, III lub IV grupy DVL lub do grupy Leistungs-Pole oraz do grup uprzywilejowanych przez okupanta, którzy do 1 stycznia 1945 r. ukończyli 14 lat. Podobnie jak w ustawie majowej, pominięto tu wpisanych do I grupy DVL. Przepisy rozporządzenia rozciagnięte zostały także na obszar byłego Wolnego Miasta Gdańska ${ }^{61}$.

Ustawa oddzielała problem wpisów na DVL dokonanych na ziemiach wcielonych do Rzeszy, gdzie powszechnie zmuszano do przyjęcia narodowości niemieckiej, od wpisów dokonanych na obszarach, na których takiego przymusu nie było (dawny Okręg Rzeszy Kraj Warty [Reichsgau Wartheland] oraz część północnego Mazowsza - rejencja ciechanowska włączona do prowincji wschodniopruskiej - Provinz Ostpreussen). W tym drugim przypadku reprezentanci DVL musieli udowodnić, że zostali na nią wpisani wbrew własnej woli. Ministerstwo Administracji Publicznej ustaliło i ogłosiło w formie

${ }^{57}$ Dz.U. RP, nr 17, 1945 r., poz. 96.

58 Dz.U. RP, nr 21, 1945 r., poz. 128: rozporządzenie MAP z 25 maja 1945 r. w sprawie rehabilitacji osób wpisanych do trzeciej i czwartej grupy niemieckiej listy narodowej lub do grupy Leistungs-Pole; Dz.U. RP, nr 21, 1945 r., poz. 130: rozporządzenie Ministra Sprawiedliwości z 26 maja 1945 r. w sprawie rehabilitacji osób wpisanych do drugiej, trzeciej i czwartej grupy niemieckiej listy narodowej lub zaliczonych do jednej z grup uprzywilejowanych przez okupanta; Dz.U. RP, nr 21, 1945 r., poz. 129: rozporządzenie Ministra Bezpieczeństwa Publicznego z 26 maja 1945 r. w sprawie wydawania zastępczych dowodów tożsamości, zob. też AAN, MAP, 199/766, Rehabilitacja osób wpisanych na niemieckie listy narodowościowe, k. 49-52, 47-48; Archiwum Państwowe w Bydgoszczy [dalej: AP Bd], Urząd Wojewódzki Pomorski [dalej: UWP[, 851/555, Wydzial Spoleczno-Polityczny, k. 5-8.

59 AAN, MAP, 199/766, Rehabilitacja osób wpisanych na niemieckie listy narodowościowe, k. 11-12;16-17, 19.

${ }^{60}$ A. Piasek, Przestepstwa okupacyjne, s. 113.

${ }^{61}$ M. Piekarski, Wylqczenie wrogich elementów, s. 39 i 116-117. 
obwieszczenia tereny, na których stosowano powszechny przymus wpisywania na DVL oraz oznaczyło te tereny, gdzie przymusu nie było ${ }^{62}$.

Postępowanie rehabilitacyjne miało charakter indywidualny, a jego istotą było oczyszczenie z zarzutów nielojalności wobec narodu i państwa polskiego pod wpływem wpisu na DVL. Zastosowanie środków zabezpieczających nie następowało automatycznie po ustaleniu faktu odstępstwa od narodowości polskiej, ale obejmowano nimi osoby, którym nie udzielono rehabilitacji w procedurze przewidzianej przez ustawę $e^{63}$.

Podobnie jak w rozwiazaniach zawartych w ustawie lutowej, jako warunek otrzymania pełni praw obywatelskich przyjęto złożenie w starostwie powiatowym lub zarządzie miejskim Deklaracji wierności Narodowi demokratycznemu Państwu Polskiemu. W treści oświadczenia umieszczono stwierdzenie o wpisie wbrew własnej woli lub pod wpływem przymusu. Ostateczny termin składania deklaracji ustalono na 31 sierpnia 1945 r., natomiast osoby przymusowo wywiezione za granicę przez okupacyjne władze niemieckie mogły składać wnioski rehabilitacyjne w ciagu miesiąca od dnia powrotu do kraju, nie później jednak niż w ciagu roku od zakończenia wojny. Władze administracji ogólnej pierwszej instancji przeprowadzającej proces rehabilitacji zobowiązane były przekazać rejestr deklaracji wierności urzędom bezpieczeństwa publicznego ${ }^{64}$. Warto zaznaczyć, że ustawa majowa pominęła osoby, które zgłosiły swój akces na volkslistę na rozkaz organizacji niepodległościowej.

Osoba pozytywnie zrehabilitowana otrzymywała zaświadczenie tymczasowe, ważne przez sześć miesięcy, które gwarantować miało prawa obywatelskie. Ten półroczny okres przejściowy przeznaczony był na publiczne ogłaszanie nazwisk osób zrehabilitowanych. Informacje zamieszczano na specjalnych tablicach w zarządach miejskich lub starostwach w miejscu wpisu na DVL i w obecnym miejscu zamieszkania. Ponadto ogłoszenia publikowano w miejscowej prasie. Zawierały one wezwanie do wszystkich osób, które wiedziałyby o tym, że któraś z osób wymienionych w ogłoszeniu została z własnej woli wpisana do III lub IV grupy DVL lub też zachowanie się jej w okresie okupacji nie dało się pogodzić z polską odrębnością narodową, do powiadomienia o tym miejscowego Urzędu Bezpieczeństwa Publicznego lub prokuratury Specjalnego Sądu Karnego. Po tym czasie swoistej kwarantanny

${ }^{62}$ AP Gd, UW, 1164/361, Sprawy rehabilitacyjne, k. 69. Jako objęte przymusem wpisowym uznane zostały obszary województwa krakowskiego (powiat bialski), gdańskiego, pomorskiego (bez powiatów włocławskiego, lipnowskiego, rypińskiego i nieszawskiego), śląsko-dąbrowskiego (bez powiatów będzińskiego, zawierciańskiego i miasta Sosnowiec), warszawskiego (powiat działdowski) oraz powiat kępiński z województwa poznańskiego, zob. też: L. Olejnik, Polityka narodowościowa, s. 157.

${ }^{63}$ M. Piekarski, Wyłaczenie wrogich elementów, s. 84. Trudno zweryfikować tezę E. Gierka o tym, że w gronie centralnego kierownictwa PPR część jej działaczy opowiadało się za sądowym trybem rehabilitacyjnym dla wszystkich wpisanych na DVL, zob. E. Gierek, Smak życia, s. 60.

${ }^{64}$ AP Gd, Miejska Rada Narodowa i Zarząd Miejski w Gdańsku [dalej: MRN/ZMG], 1 165/379, Lustracja i zarzadzenia polustracyjne, k. 12. 
następowało przyznanie zaświadczenia stałego. Wobec osób, które w określonym terminie nie złożyły wniosku rehabilitacyjnego stosowano paletę „środków zabezpieczających”, zawartych w ustawie listopadowej: umieszczenie w miejscu odosobnienia na czas nieokreślony, poddanie przymusowej pracy, stała utrata praw publicznych oraz obywatelskich praw honorowych, konfiskata mienia.

W przypadku osób zaliczonych do II grupy DVL do uzyskania rehabilitacji, tak jak przewidziano w ustawie lutowej, obowiązywało postępowanie sądowe ${ }^{65}$. W trakcie trwania procesu należało udowodnić, że mimo posiadanej grupy zachowano polską odrębność narodową. Do rehabilitacji sądowej zobowiązano również posiadaczy III grupy DVL, wobec których niemieckie władze okupacyjne zrzekły się odwołania ich niemieckiej przynależności państwowej oraz osoby ${ }^{6}$.

Proceder sądowej rehabilitacji wszczynano przez złożenie pisemnego wniosku o odzyskanie pełni praw obywatelskich w Sązie Grodzkim, właściwym miejscu zamieszkania w dniu 1 stycznia 1945 r. Po uiszczeniu opłaty przez wnioskodawcę (w postępowaniu dowodowym występował w roli oskarżonego) zamieszczano w budynku sądu oraz rady narodowej, właściwej według miejsca zamieszkania wnioskodawcy, ogłoszenie o wszczęciu procesu rehabilitacyjnego. Ponadto informację na ten temat sąd mógł zamieścić w miejscowej prasie. Ogłoszenia te zawierały wezwania do osób, które miały wiedzę obciążającą wnioskodawcę w kwestii jego ewentualnej działalności na szkodę narodu i państwa polskiego w okresie wojny; osoby te miały powiadomić o tym władze bezpieczeństwa lub prokuratora SSK. Od momentu zamieszczenia publicznej informacji do momentu wszczęcia postępowania sądowego musiało upłynąć co najmniej 30 dni. Sprawę o rehabilitację rozpatrywał sędzia wraz z dwoma ławnikami, powoływanymi przez prezydium miejskiej lub gminnej rady narodowej. Do rozprawy, która miała charakter jawny, swój udział mógł zgłosić prokurator SSK lub urzędnik organów bezpieczeństwa.

W przypadku pozytywnego zakończenia sądowego trybu rehabilitacyjnego sąd wydawał orzeczenie, w którym przyznawał wnioskodawcy pełnię praw obywatelskich oraz zarządzał zwolnienie jego majątku spod zajęcia, dozoru i zarządu. Natomiast w sytuacji przeciwnej, sąd mógł nakazać umieszczenie wnioskodawcy na czas nieokreślony w miejscu odosobnienia, poddanie przymusowej pracy, utratę praw publicznych oraz obywatelskich praw honorowych, jak też przepadek mienia ruchomego i nieruchomego wnioskodawcy, a także jego rodziny. Nieuwzględnienie wniosku rehabilitacyjnego przez Sąd Grodzki było równoznaczne z przekazaniem akt sprawy SSK, który przeprowadzał dochodzenie w sprawach o popełnienie czynów określonych dekretem

${ }^{65}$ AP Gd, UW, 1164/ 358, Sprawy narodowościowe (autochtonów i ich weryfikacji), k. 85.

th "Eingedeutsche" $i$,volksdeutsche" przed sadem rehabilitacyjnym, "Dziennik Baltycki" 1945 , nr 9, s. 3. 
o wymiarze kary dla zbrodniarzy faszystowsko-hitlerowskich ${ }^{67}$. Prokurator tego sądu miał prawo do złożenia zażalenia na postanowienie Sądu Grodzkiego $\mathrm{w}$ terminie do 30 dni od momentu otrzymania wyroku skazującego. Tryb odwoławczy, który miał jawny charakter, rozpatrywał SSK w składzie trzech sędziów. Podobnie jak w ustawie lutowej, ustanowiono dziesięcioletni okres, podczas którego organa bezpieczeństwa lub prokurator SSK mógł wnieść o ponowne rozpatrzenie danej sprawy z uwagi na pojawienie się nowych okoliczności.

W grudniu 1945 r. Ministerstwo Administracji Publicznej zwróciło się do Ministerstwa Sprawiedliwości z prośbą o wydanie sądom grodzkim zarządzenia w sprawie powiadamiania przez te ostatnie o negatywnych postanowieniach rehabilitacyjnych właściwe terytorialnie władze administracyjne ${ }^{68}$.

Dla osób udzielających pomocy reprezentantom DVL, którzy nie złożyli w terminie wniosku rehabilitacyjnego lub też został on odrzucony, ustawa majowa przewidywała karę więzienia od 5 lat bądź karę śmierci.

Dekretem z 6 czerwca $1945 \mathrm{r}^{69}$ o kosztach sądowych procesu rehabilitacyjnego ustalono kwotę 500 zł, którą należało uiścić wraz ze złożeniem wniosku o przywrócenie pełni praw obywatelskich. Ponadto wraz z wydaniem pozytywnego wyroku sąd wedhug uznania mógł pobrać opłatę od 100 do $5000 \mathrm{zl}$.

$Z$ uwagi na bardziej skomplikowany tryb rozpatrywania wniosków volksdeutchów zagadnieniem tym w sposób szczególny zajął się Polski Związek Zachodni. Podjął on działania zmierzające w kierunku szybkiego ukończenia akcji rehabilitacyjnej, głównie na terenie Górnego Śląska ${ }^{70}$.

Ministerstwo Bezpieczeństwa Publicznego wydało zarządzenie o udostępnieniu osobom wpisanym do II, III i IV grupy DVL lub do grupy tzw. Leistungs-Pole i znajdujących się w więzieniach, obozach i aresztach składania Deklaracji wierności oraz wniosków rehabilitacyjnych do 15 sierpnia 1945 r. Naczelnikom więzień polecono sporządzenie list tych osób. Jednocześnie Ministerstwo Administracji Publicznej poleciło wojewodom, by ci nakazali starostom powiatowym i prezydentom miast (pełniących zarazem funkcję starostów grodzkich) delegowanie do miejsc odosobnienia urzędników w celu przyjęcia Deklaracji wierności i wydania zaświadczeń rehabilitacyjnych, zgodnie $\mathrm{z}$ rozporządzeniem z 25 maja $1945 \mathrm{r}^{71}$

Ustawa majowa była trzykrotnie nowelizowana. Po raz pierwszy dekretem z 24 sierpnia $1945 \mathrm{r}^{72}$, który wprowadził na terenach objętych powszechnym

${ }^{67}$ M. Romaniuk, Podzwonne okupacji. Deutsche Volksliste w Bydgoszczy (1945-1950), Bydgoszcz 1993, s. 59.

68 AAN, MAP, 199/766, Rehabilitacja osób wpisanych na niemieckie listy narodowościowe, k. 68 .

${ }^{69}$ Dz.U. RP, nr 25, 1945 r., poz. 150.

${ }^{70}$ C. Osękowski, Spoleczeństwo, s. 101-102.

71 AAN, MAP, 199/766, Rehabilitacja osób wpisanych na niemieckie listy narodowościowe, k. 62-63.

72 Dz.U. RP, nr 34, 1945 r., poz. 203; M. Ujdak, Polski Zwiazek Zachodni, s. 106-107. 
przymusem wpisu na DVL - w miejsce zaświadczeń tymczasowych - zaświadczenia stałe stwierdzające obywatelstwo polskie. Zniesienie tych pierwszych zlikwidowało okres przejściowy przeznaczony na publiczne ogłaszanie nazwisk osób zrehabilitowanych. Inicjatywę w tym zakresie podjęła grupa posłów z województwa śląsko-dąbrowskiego ${ }^{73}$. Ostatecznie doprowadziła ona do przeprowadzania akcji rehabilitacji na terenach, na których obowiązywał przymus wpisowy, w drodze administracyjnej. Jakkolwiek przyznanie zaświadczenia stałego, świadczącego o pełnej rehabilitacji nie stało w sprzeczności z możliwością późniejszego wszczęcia procedury sądowej w sprawie o odstępstwo od narodowości polskiej.

Druga nowelizacja ustawy majowej nastapiła wraz z wydaniem dekretu w dniu 30 października 1945 r., który zniósł zapis artykułu 16 ustawy majowej przewidujący zwolnienie majątku spod zajęcia w przypadku orzeczenia rehabilitacji ${ }^{74}$. Umożliwiała ona nieoddanie gospodarstwa lub mieszkania dotychczasowym właścicielom, którzy zapisani byli do grupy II oraz III, gdzie okupant zrzekł się odwołania niemieckiej przynależności państwowej. Postawiona w takiej sytuacji osoba miała jedynie prawo do odszkodowania ze strony Skarbu Państwa. Nowela ta dostosowywała stan prawny do stanu rzeczywistego, umożliwiając osadnikom i repatriantom zatrzymanie przejętych przez nich nieruchomości przed 1 sierpnia 1945 r., zamieszkałych dotąd przez Polaków, którzy nie przeszli jeszcze rehabilitacji ${ }^{75}$.

Komisja Prawnicza Instytutu Śląskiego przygotowała projekt ustawy O jednolitym uregulowaniu zagadnień zdrady Narodu i Państwa $w$ okresie okupacji hitlerowskiej $w$ Polsce ${ }^{76}$. Zawarte w nim propozycje w wysokim stopniu znalazły odzwierciedlenie w trzeciej z kolei noweli ustawy z 6 maja 1945, uchwalonej w dniu 22 lutego $1946 \mathrm{r}^{77}$, dopuszczającej częściową rehabilitację. Ograniczenie polegało na możliwości czasowego (do 5 lat) zawieszenia praw publicznych i obywatelskich praw honorowych do 5 lat albo/lub przy jednoczesnym nałożeniu grzywny (od 500 do $2 \mathrm{mln}$ zł) bądź przepadkiem mienia w całości lub w części. Uważa się, że zasada ograniczonej rehabilitacji umożliwiła sądowi uwzględnienie w orzeczeniu wszystkich okoliczności sprawy, a przede wszystkim postawę wnioskodawcy w okresie okupacji oraz korzyści odniesione $\mathrm{z}$ racji przyjęcia DVL ${ }^{78}$. Równolegle dopuszczono nie-

73 J. Gołębiowski, Kwestia narodowościowa w polityce wladzy ludowej w województwiéslasko-dabrowskim (1945-1947), „Kwartalnik Historyczny” 1964, nr 2, s. 396.

74 Dz.U. RP, nr 55, 1945 r., poz. 307.

${ }^{75}$ Zob. A. Pasek, Przestepstwa okupacyjne, s. 125; C. Wasilkowski, Skutki odstępstwa od narodowości w czasie wojny w zakresie praw majatkowych, „Demokratyczny Przegląd Prawniczy” 1947 , nr 5, s. 37 k. $82-98$

AAN, MAP, 199766, Rehabilitacja osób wpisanych na niemieckie listy narodowościowe,

${ }_{77}^{7}$ Dz.U. RP, nr 11, 1946 r., poz. 73; M. Ujdak, Polski Zwiazek Zachodni, s. 108.

${ }^{78}$ A. Landau, C. Wasilkowski, Zagadnienie tzw. volksdeutschów, s. 10. Zob. też A. Pasek, Przestepstwa okupacyjne, s. 126-127. 
jawny tryb rozpatrywania sprawy, jeśli wniosek rehabilitacyjny zasługiwał na uwzględnienie oraz możliwość rozpatrywania go pod nieobecność wnioskodawcy $^{79}$. Dotąd bowiem jego nieusprawiedliwiona nieobecność bywała powodem odmowy rehabilitacji, co w konsekwencji groziło skierowaniem do obozu pracy. Jeśli sąd uznał, że obecność wnioskodawcy na rozprawie jest konieczna, mógł nakazać sprowadzenie go z obozu. Wnioski rehabilitacyjne złożone po terminie również mogły być rozpatrywane na posiedzeniu niejawnym. W przypadku wyroku skazującego prokurator SKK zarządzał aresztowanie, umieszczenie wnioskującego w miejscu odosobnienia. Osoby, które nie zgłosiły woli rehabilitacji w wyznaczonym terminie podlegały osadzeniu w obozie na czas nieokreślony oraz przymusowej pracy. $Z$ kolei osoby, które wiedząc o szkodliwej dla narodu polskiego wojennej działalności wnioskującego nie powiadomiły o tym władz bezpieczeństwa publicznego, Sądu Grodzkiego lub prokuratora Specjalnego Sądu Karnego, mogły zostać skazane na karę więzienia do pięciu lat.

Omawiana nowela ustawy majowej stanowiła pomost między stosowaniem ,środków zabezpieczających” a zasadą osądzenia i ukarania współmiernie do stopnia zawinienia ${ }^{80}$. Jej urzeczywistnienie nastapiło cztery miesiące później, kiedy 28 czerwca 1946 r. został wydany dekret $O$ odpowiedzialności karnej za odstepstwo od narodowości w czasie drugiej wojny światowej ${ }^{81}$. Ustawa ta zadośćuczyniła postulatom, które Ministerstwo Sprawiedliwości w formie Memorialu przygotowało w kwietniu tego roku ${ }^{82}$. Zawierał on dezyderat, że należy zerwać z partykularyzmem ustawodawczym odnośnie do odstępstwa od narodowości polskiej w czasie okupacji na rzecz ujednolicenia przepisów prawnych w tym zakresie na całym obszarze Polski. Proponowano odrzucenie zasady, że o sytuacji prawnej danej osoby decydowała przynależność do konkretnej grupy DVL. Ponadto postulowano zaprzestanie stosowania „środków zabezpieczających” wobec Polaków wpisanych na DVL. W celu ostatecznego rozwiązania omawianego problemu należało wysiedlić z Polski ludność niemiecka, wobec której przygotowywano odrębne przepisy prawne ${ }^{83}$.

Pierwotnie dekret objął przedstawicieli volkslisty z województwa śląsko-dąbrowskiego. Rozporządzeniem Rady Ministrów z 19 września 1946 r. roz-

${ }^{79}$ M. Romaniuk, Podzwonne okupacji, s. 61-62.

${ }^{80}$ A. Landau, C. Wasilkowski, Zagadnienie tzw. volksdeutschów, s. 8.

${ }^{81}$ Dz.U. RP, nr 41, 1946 r., poz. 237. Zob. też AAN, MAP, 199/766, Rehabilitacja osób wpisanych na niemieckie listy narodowościowe, k. 109-116; AP Gd, MRN/ZMG, 1165/1358, Przepisy $i$ zarzadzenia odnoszace się do osób pozbawionych obywatelstwa polskiego oraz rejestr osób pozbawionych obywatelstwa, Dekret, k. 195-200.

${ }^{k 2}$ Z. Boda-Krężel, Sprawa Volkslisty, s. 105-106; M. Romaniuk, Podzwonne okupacji, s. 65-66.

${ }^{83}$ Dekret z 13 września 1946 r. O wylqczeniu ze spoleczeństwa polskiego osób narodowości niemieckiej, Dz.U. RP, nr 55, 1946 r., poz. 310. Zasadniczym kryterium, jakim miano się kierować przy pozbawianiu obywatelstwa polskiego było zachowanie niemieckiej odrębności narodowej oraz zachowanie wobec Polaków podczas wojny. Szerzej na ten temat zob. L. Olejnik, Zdrajcy, s. $185-186 \mathrm{i}$ in. 
ciągnięto go na terytorium całego kraju. Zdjęło ono odpowiedzialność władz administracyjnych pierwszej instancji za prowadzenie akcji rehabilitacji. Wszystkie sprawy miały być odtąd kierowane do prokuratorów sądów okręgowych, natomiast, jak juź wspomniano, instytucja SSK uległa zniesieniu. Przepisy dekretu obejmowały osoby, których postępowanie rehabilitacyjne nie zostało jeszcze zakończone bądź wszczęte. Od odpowiedzialności karnej wyłączono osoby, które wcześniej otrzymały zaświadczenia o obywatelstwie polskim oraz osoby narodowości niemieckiej ${ }^{84}$.

I tak z dniem 21 października 1946 r., a więc w chwili ogłoszenia rozporządzenia w Dzienniku Ustaw $\mathrm{RP}^{85}$ na terenie całego kraju straciły moc obowiąującą zarówno przepisy o środkach zabezpieczających w stosunku do zdrajców narodu, jak i o wyłączeniu ze społeczeństwa polskiego wrogich elementów.

Liberalizacja ustawy polegała na wyłączeniu od odpowiedzialności karnej następujących kategorii osób, które przyjęły DVL:

1) z zamiarem działania $w$ interesie państwa polskiego albo z nakazu lub na rzecz polskiej organizacji wolnościowej,

2) w celu uniknięcia ciężkiego prześladowania ze strony władz albo organizacji niemieckich, jeżeli prześladowania nie można było uniknąć w inny sposób,

3) w celu brania udziału w kraju lub zagranicą w walkach wyzwoleńczych, dobrowolnego wstapienia do wojska lub organizacji wolnościowej, walczącej z państwem niemieckim,

4) i jednocześnie z narażeniem wolności lub życia czynnie okazywały pomoc społeczeństwu polskiemu.

Osoby, które przyjęły ,grupę" z innych niż wymienione wyżej powody podlegały karze do 10 lat więzienia, grzywny, przepadkowi mienia w całości lub w części, a także dodatkowej karze utraty praw publicznych lub obywatelskich praw honorowych. Przewidziano równolegle możliwość złagodzenia kary, jeżeli przyjęcie DVL nastappiło ,wskutek ciemnoty lub usprawiedliwionego warunkami życia braku wyrobienia obywatelskiego". Wprowadzono tym samym tzw. rehabilitację w ograniczonym rozmiarze ${ }^{86}$.

Dekret zatwierdzał wydane dotąd wyroki SSK, uchylające zarządzenia prokuratora o przymusowym odosobnieniu, a także postanowienia sądów grodzkich o pełnej lub częściowej rehabilitacji oraz zaświadczenia o obywatelstwie i narodowości polskiej. Ponadto odstapiono od kary osadzenia w miejscu odosobnienia, poddania przymusowej pracy, natomiast wydane w tym zakresie orzeczenia traciły moc prawna, z wyjattkiem wyroków o przepadku mienia lub też kar grzywny. Uważa się, że dekret czerwcowy zawęził grono osób, wobec których można było wszcząć postępowanie za odstępstwo

\footnotetext{
${ }^{84}$ M. Ujdak, Polski Zwiqzek Zachodni, s. 109

${ }^{85}$ Dz.U. RP, nr 53, 1946 r., poz. 300.

${ }^{86}$ M. Ujdak, Polski Zwiazek Zachodni, s. 109.
} 
od narodowości polskiej, jak też, że skierowany był do osób, wobec których istniało domniemanie, że byli Polakami ${ }^{87}$.

Ostatnim aktem legislacyjnym, który w kontekście prawnym likwidował skutki volkslisty była ustawa amnestyjna z 20 lipca 1950 r. O zniesieniu sankcji oraz ograniczeń w stosunku do obywateli, którzy zgłosili swa przynależność do narodowości niemieckiej ${ }^{88}$. Rozporządzenie to zawieszało wszczynanie procesów wobec obywateli polskich, którzy w okresie od 1 września 1939 do 9 maja 1945 r. zgłosili przynależność do narodowości niemieckiej bądź pochodzenie niemieckie, lub też akces do innej uprzywilejowanej grupy. Rozpoczęte już postępowania umorzono, natomiast niewykonane dotąd sankcje karne darowano oraz cofnięto orzeczone pozbawienia praw publicznych $i$ honorowych. Natomiast jako pełnoprawne uznano wyroki o konfiskacie mienia, zapadłe do chwili wejścia w życie ustawy. Przy czym, jeśli majątek w tym okresie pozostawał jeszcze w posiadaniu właściciela, mogło nastapić jego zwolnienie spod zajęcia, dozoru lub zarządu ${ }^{89}$. Ustawa nie objęła swym zasięgiem przestępstw sądzonych z omówionego wyżej dekretu sierpniowego. Grupę tych wykroczeń regulowały przepisy ustawy amnestyjnej z kwietnia 1956 r. ${ }^{90}$

Kolejnym krokiem w celu ostatecznego rozstrzygnięcia sytuacji osób wciąż pozbawionych obywatelstwa polskiego, a pozostających w kraju, była uchwała Prezydium Rady Ministrów z 18 lipca $1951 \mathrm{r} .{ }^{91}$ Upoważniała ona prezydia wojewódzkich rad narodowych do uchylenia z urzędu wyroków o pozbawieniu obywatelstwa, przepadku mienia oraz wysiedleniu. Warunkiem, jaki należało spełnić, by móc podlegać przepisom tej uchwały, było niepiastowanie ważnych stanowisk w NSDAP, policji lub innych formacjach i organizacjach hitlerowskich ${ }^{92}$. Wreszcie osoby posiadające wpis na Deutsche Volksliste, a zamieszkujące w Polsce co najmniej od 9 maja 1945 r., mogły podjąć starania o nadanie obywatelstwa polskiego przez Radę Państwa na podstawie ustawy z 8 stycznia 1951 r. o obywatelstwie polskim ${ }^{93}$. Zniosła ona zależność między narodowością a obywatelstwem polskim.

Ogółem w latach 1944-1950 wydano 27 ustaw, dekretów oraz rozporządzeń dotyczących ,zdrady narodu” oraz „odstępstwa od narodowości polskiej”"94.

${ }^{87}$ L. Olejnik, Zdrajcy, s. 185.

${ }^{88}$ Dz.U. RP nr 29, 1950 r., poz. 270; AIPN Gd, 0046/233 t.1, k. 56.

89 Rozporządzenie Rady Ministrów z 26 lipca 1950 r. do ustawy amnestyjnej Ministrów 20 lipca 1950 r., Dz.U. RP nr 32, 1950 r., poz. 294.

${ }^{90}$ L. Olejnik, Zdrajcy, s. 214

91 L. Olejnik, Polityka narodowościowa, s. 186.

${ }^{92} \mathrm{~W}$ maju $1951 \mathrm{r}$. przebywało w Polsce ponad 14 tys. wciąż niezrehabilitowanych osób. Ibidem, s. 216.

${ }_{93}$ Dz.U. RP nr 4, 1951 r., poz. 25.

94 M. Motas, Przeglad przepisów karnych 1944-1956, w: Biuletyn Gtównej Komisji Badania Zbrodni przeciwko Narodowi Polskiemu Instytutu Pamięci Narodowej, t. XXXIV, Warszawa 1992, s. 142-144. 
Wysoka liczebność aktów prawnych w tym zakresie rodziła liczne zapytania i wątpliwości na gruncie wojewódzkiego czy powiatowego przebiegu akcji rehabilitacyjnej.

Proces rehabilitacji osób wpisanych na DVL jawił się jako przedłużenie skutków prowadzonej przez Niemców polityki narodowościowej w czasie wojny. Dla władzy komunistycznej stanowił nie lada wyzwanie i problem, gdyż musiała się ona zmierzyć z zagadnieniem, które generalnie nie wpisywało się w realizację głównego celu Polskiej Partii Robotniczej: monopolizacji rządów w Polsce i odbudowy kraju opartych na modelu sowieckim. Dodatkowo powojenne władze nie wypracowały jasno określonego programu wobec kwestii skutków polityki niemczenia. Dopiero analiza błędów, w tym na podstawie nadchodzących sprawozdań $z$ terenu oraz przeciagająca się procedura rehabilitacji zmusiły władze do zmiany regulacji prawnych.

Ustawodawstwo wobec wpisanych na volkslistę ulegało modyfikacjom, $\mathrm{z}$ tendencją do łagodzenia represyjnego kursu wobec tych osób tuż po zakończeniu wojny. Miało to odbicie w nazewnictwie aktów prawnych dotyczących rehabilitacji - od ,wrogich elementów” (ustawa majowa z 1945 r.) do „odstępców od narodowości polskiej" (dekret czerwcowy z 1946 r.). Należy przy tym pamiętać, że początkowy stosunek powojennych władz do omawianej problematyki w dużej mierze polegał na wygrywaniu nastrojów antyniemieckich w celu legitymizacji panowania politycznego.

Od 1951 r. problem osób wpisanych na volkslistę nie absorbował już instytucji zajmujących się problematyką narodowościową. W wymiarze formalnoprawnym jej status był uregulowany. Jednakże ta grupa ludności w dalszym ciagu pozostawała w polu zainteresowania aparatu bezpieczeństwa. Jeszcze długo postrzegano ich jako zagrożenie dla bezpieczeństwa państwa, doszukując się współpracy z obcymi wywiadami. Szerzej wpisywało się to w panująca w tym okresie atmosferę podejrzliwości wobec wielu środowisk społecznych i miało na celu podtrzymywanie postaw czujności aparatu bezpieczeństwa. 
